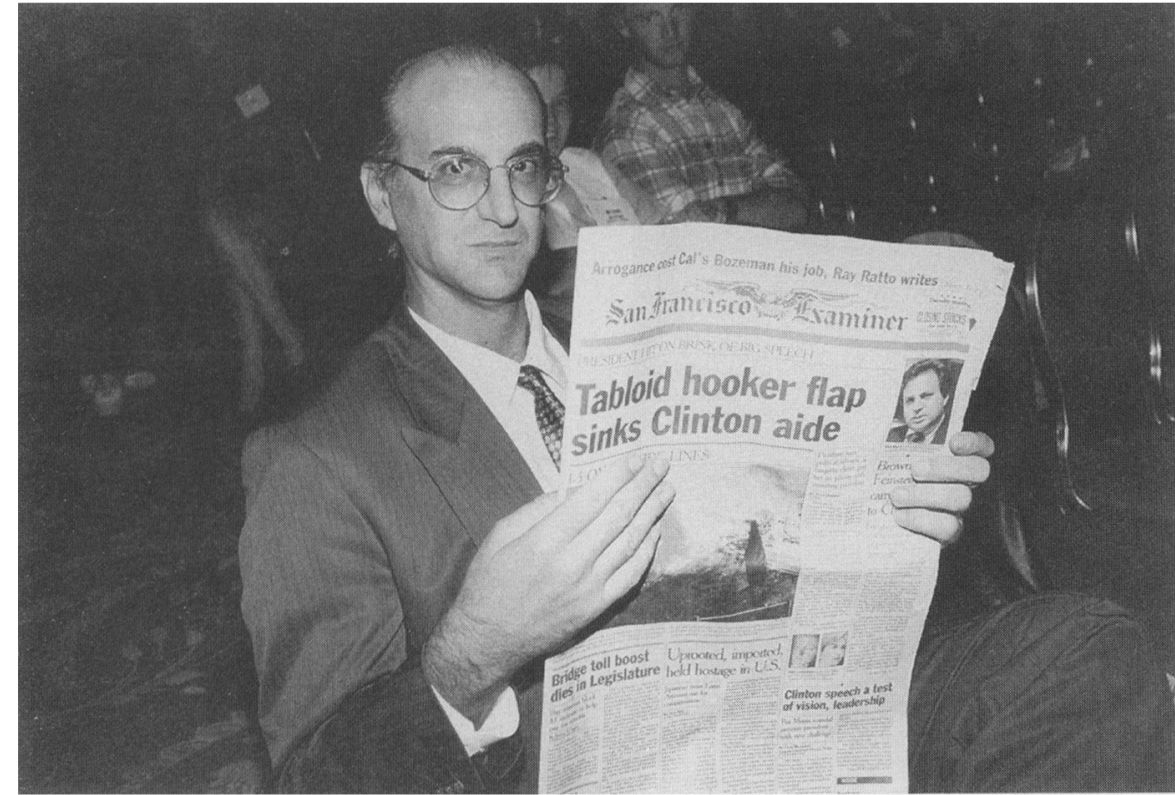

"Deja vu all over again." A member of audience takes in the days events awaiting the Pi Sigma Alpha sponsored presentation of President Clinton's acceptance speech before the Democratic National Convention.

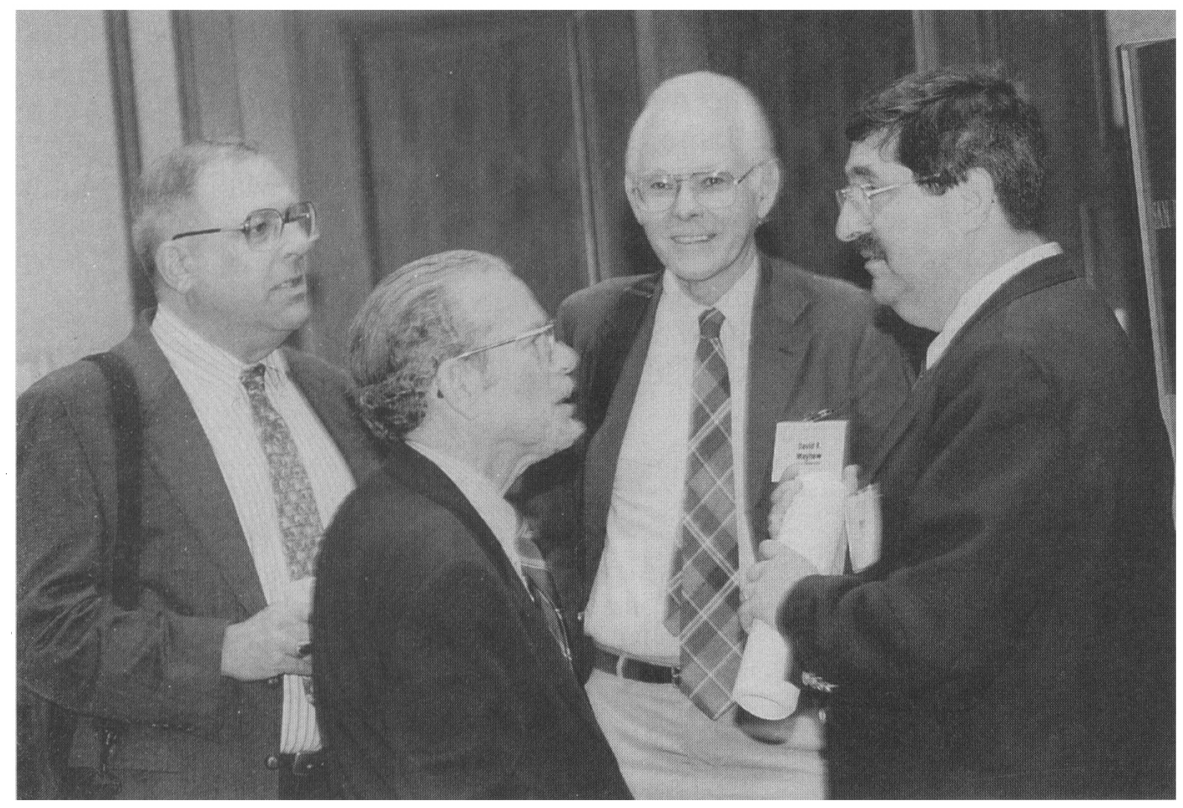

[L-R] Roger Davidson and Donald Tannebaum follow up with David Mayhew and Michael Malbin following the roundtable "The 104th Congress: Business as Usual." Joining Mayhew and Malbin on the roundtable were Richard F. Fenno, Jr., John Kornacki, Robert Peabody, and Barbara Sinclair.

Address by Arend Lijphart, University of California, San Diego, entitled "Unequal Participation: Democracy's Unresolved Dilemma."

\section{Poster Sessions a Highlight at Annual Meeting}

Poster presentations are a now proven method of sharing knowledge divided into three categories: Comparative Politics and International Relations, Political Theory and Methodology, and American Politics.

This year marked the first time extensive poster sessions were included in the Annual Meeting program. Taking hints from colleagues in the other sciences, many presenters demonstrated expertise at condensing research into a 4 foot by 8 foot poster.

The poster sessions also offered opportunities for informal, in-depth discussion of research. Presenters capitalized on the crowds, taking the chance to share greater details about their research interests with the large audience.

Recognizing the potential of poster sessions at future Annual Meetings, APSA awarded prizes for the best presentations. Four scholars walked away with certificates and cash awards. The winners and the awards committees were:

Poster Session I: Comparative Politics and International Relations

Recipient: Sandra Joireman, University of California, Los Angeles Presentation: Changing Property Rights in the Horn of Africa.

Recipient: Valentina Padula, University of Maryland, College Park Presentation: The Nature of Party Campaigning in Italy: a Study of Televised Political Ads in Four National Elections, 1983-1994.

Award Committee: Beth Simmons, Duke University, Chair; Geoffrey Garrett, University of Pennsylvania; and Steve Weber, University of California, Berkeley.

Poster Session II: Political Theory and Methodology

Recipient: Paul A. Kowart, Florida International University Presentation: The Political Personality: Q-Sort Profiles of Six Postwar American Presidents.

Award Committee: John Freeman, University of Minnesota, Chair; Anne Norton, University of Pennsylvania; and Arlene Saxonhouse, University of Michigan.

Poster Session III: American Politics

Recipient: Michael Bailey, Stanford University

Presentation: Particular and Diffuse Interests and American Trade Poli- 

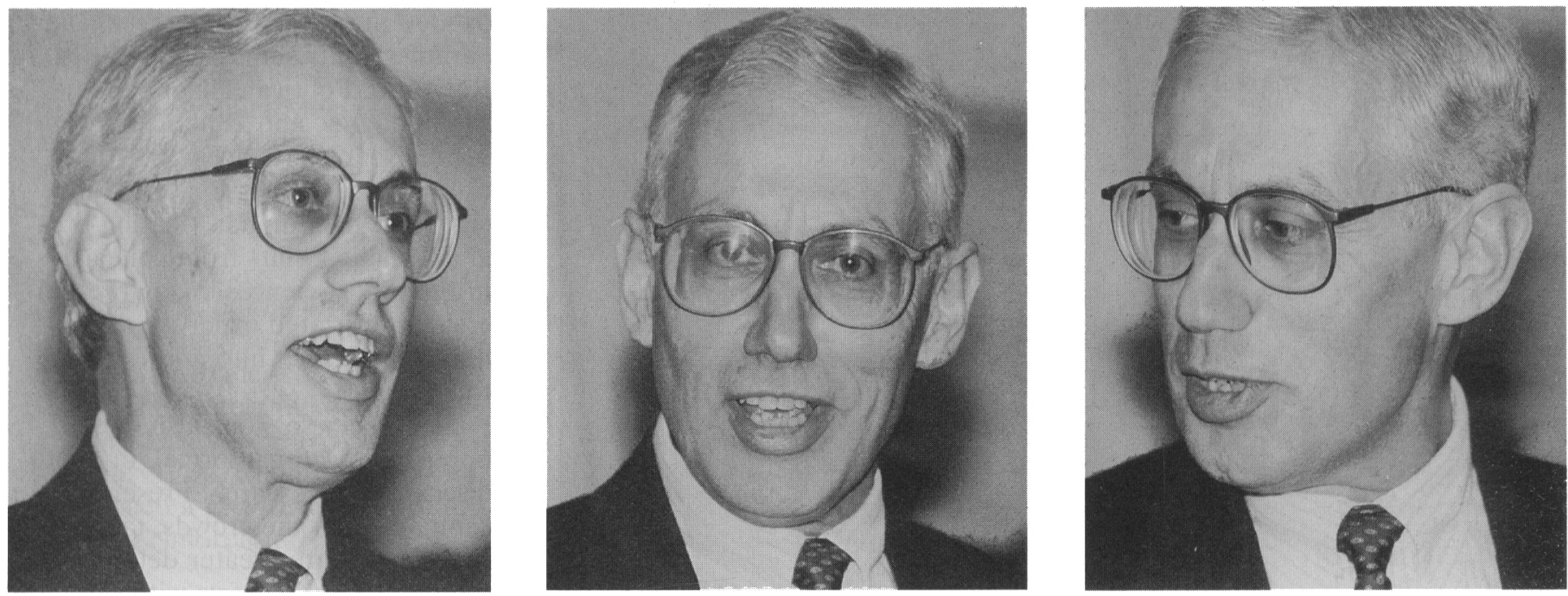

APSA President Arend Lijphart of the University of California, San Diego's Presidential Address, "Unequal Participation: Democracy's Unresolved Dilemma," will appear in the March 1997 issue of the American Political Science Review.

tics: Understanding Senate Voting on GATT and NAFTA in 1993-1994

Award Committee: Amy Bridges, University of California, San Diego, Chair; Paula D. McClain, University of Virginia; and Terry Moe, Stanford University.

The 1997 poster sessions will be organized by David Brady of Stanford University. Rules and guidelines for next year's presentations will be available in a subsequent issue of $P S$.

\section{Association Distributes Annual Awards}

The 1996 APSA Awards Ceremony, held August 30 in conjunction with the Annual Meeting, featured a slate of 18 awards, including the Association's highest honor, the James Madison Award. Former APSA president Philip Converse (1984-85), was selected winner of the triennial Madison Award honoring a career of scholarly excellence, including directorship of The Center for Advanced

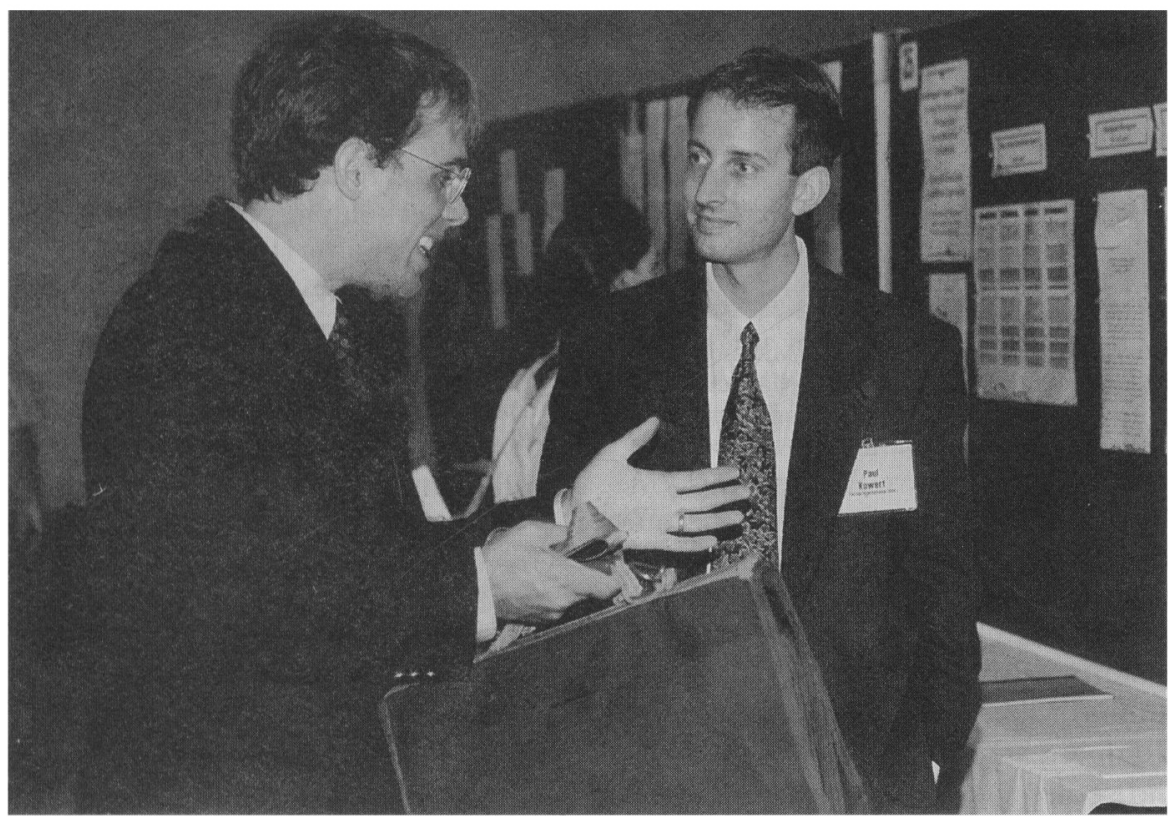

The Poster Session on Political Theory and Methodology. Paul Kowert [R], Florida International University, winner of the session's best poster award listens to comments on his presentation "The Political Personality: Q-Sort Profiles of Six Postwar American Presidents."
Study in the Behavorial Sciences. Madison Award Committee chair Edward Keller noted “... through his mastery of our discipline as author, teacher, mentor and colleague, (Converse) has made a remarkable scholarly contribution to the discipline." Earlier in the day Converse delivered the 1996 Madison Lecture, "The Advent of Polling and Political Representation." A printed version of the lecture can be found in this issue of $P S$.

The 1996 John Gaus Distinguished Lecturer Award was presented to Lynton K. Caldwell of Indiana University. The Gaus Award is presented annually to honor a lifetime of exemplary scholarship in the joint tradition of political science and public administration, and more generally, recognizes and encourages scholarship in public administration. "Trained as a political scientist, yet stimulated by interactions with other disciplines, Caldwell took the road less traveled and made himself an interdisciplinary scholar," said Gaus Committee Chair Rosemary O'Leary during her introduction of Caldwell at the lecture presentation. Caldwell's lecture, "The State as a Work of Art: Statecraft for the 21st Century," is featured in this issue of $P S$.

Nine young scholars were recognized at the Awards Ceremony for their outstanding dissertations completed during the 1994-95 academic years. Eight dissertation prizes were presented, including, the Gabriel A. 